\title{
Synergistic effects of the methanol extract of Trichosanthes kirilowii with antibiotics against oral pathogens
}

\author{
Eun-Jin Jang ${ }^{1}$, Sung-Mi Choi ${ }^{2}$ and Jeong-Dan Cha ${ }^{3 *}$ \\ ${ }^{1}$ Department of Dental Technology, Daegu Health College, Daegu, Republic of Korea \\ ${ }^{2}$ Department of Dental Hygiene, Daegu Health College, Daegu, Republic of Korea \\ ${ }^{3}$ Department of Oral Microbiology and Institute of Oral Bioscience, Chonbuk National University, Jeonju, South Korea
}

\begin{abstract}
Trichosanthes kirilowii is a traditional medicine used in East Asia for treating patients with diabetes, cancer-associated symptoms, hepatoprotective, coughing, breast abscesses, antibacterial, and antiviral activity. This study aimed to investigate the synergistic antibacterial activity of the methanol extract of Trichosanthes kirilowii (METK) with existing antimicrobial agents against oral pathogen. The synergistic effects and anti-biofilm of METK were evaluated against oral bacteria, either alone or with antibiotics, via broth dilution method and crystal violet assays. MIC/MBC values for METK, ampicillin, and gentamicin against all the tested bacteria ranged between 156-2500/313-5000 microg/mL, 0.25-64/0.25-64 microg/mL, and 0.5-256/1-512 microg/mL, respectively. The synergistic effects were exhitited on METK with antibiotics against oral bacteria at fractional inhibitory concentration index (FICI) $<0.5$. Moreover, METK and antibiotics were found to synergistically reduce biofilm formation. 1-6 hours of treatment with 1/2 MIC of METK with $1 / 2 \mathrm{MIC}$ of antibiotics resulted from an increase of the rate of killing in units of CFU/mL to a greater degree than was observed with alone except $S$. sanguinis on ampicillin and $S$. criceti, S. anginosus, and $S$. gordonii on gentamicin. These results suggest that the methanol extract of Trichosanthes kirilowii (METK) is important in the antibacterial actions of oral pathogen agents.
\end{abstract}

\begin{abstract}
Abbreviations: METK: the methanol extract of Trichosanthes kirilowii; MICs: Minimum inhibitory concentrations; MBCs: Minimum bactericidal concentrations; CFU: Colony Forming Unit; FIC index: Fractional inhibitory concentration; FBC index: Fractional bactericidal concentration index.
\end{abstract}

\section{Introduction}

Oral diseases are major health problems with dental caries and periodontal diseases among the most important preventable global infectious diseases [1]. Oral health influences the general quality of life and poor oral health is linked to chronic conditions and systemic diseases [2]. Oral biofilm acquires new microbial species in each stage of its development, including Lactobacillus casei, Streptococcus sanguis, S. mutans, S. mitis and S. sobrinus, which due their pathogenicity could damage the enamel and gum tissue [3]. Diseases appear in this microenvironment when there is a lack of equilibrium in the ecosystem of the bacterial biofilm formed, and thus the mechanical removal of the biofilm is an important factor to prevention of caries and periodontal diseases $[4,5]$. The development of dental caries involves acidogenic and aciduric gram-positive bacteria, primarily the mutans streptococci (S. mutans and S. sobrinus), lactobacilli, and actinomycetes, which metabolize sucrose to organic acids (mainly lactic acid) that dissolve the calcium phosphate in teeth, causing decalcification and eventual decay [6]. Periodontal disease results from chronic infection and inflammation of the tissues that support the teeth [7].

Trichosanthes kirilowii is a traditional medicine used in East Asia for treating patients with diabetes, cancer-associated symptoms, coughing, and breast abscesses [8-11]. Trichosanthin (TCS), which is also known as type 1 ribosome-inactivating protein, is a chemical component derived from Trichosanthes kirilowii [12]. TCS acts as a potent inhibitor of HIV-1 replication and is known to have various antitumor functions [13]. Recently, it was reported that Cucurbitacin D, isolated from Trichosanthes kirilowii, have been known for their anti-inflammatory, antimicrobial, and antitumor activities [14,15]. Cucurbitacins refer to a group of tetracyclic triterpenoids initially identified in the plant family of Cucurbitaceae [16,17].

In this study, the antimicrobial activities of the methanol extract of Trichosanthes kirilowii (METK) against oral bacteria were assessed using broth microdilution method and time-kill methods and crystal violet assay for synergistic effect and biofilm formation of the combination with antibiotics.

\section{Materials and methods \\ Bacterial strains}

The oral bacterial strains used in this study were: Streptococcus mutans ATCC 25175, Streptococcus sanguinis ATCC 10556, Streptococcus sobrinus ATCC 27607, Streptococcus ratti KCTC (Korean collection for type cultures) 3294, Streptococcus criceti KCTC 3292, Streptococcus anginosus ATCC 31412, Streptococcus gordonii ATCC 10558, Aggregatibacter actinomycetemcomitans ATCC 43717,

${ }^{\star}$ Correspondence to: Jeong-Dan Cha, Department of Oral Microbiology and Institute of Oral Bioscience, Chonbuk National University, 664-14 DuckjinDong, Duckjin-Ku, Jeonju, Chonbuk, 561-756 Republic of Korea, Tel: +82-63270-4023; Fax: +82-63-270-4049; E-mail: joungdan@chonbuk.ac.kr

Key words: Trichosanthes kirilowii, antibacterial activity, oral pathogen, biofilm formation, synergistic effect, minimum inhibitory concentrations (MICs), minimum bactericidal concentrations (MBCs)

Received: September 15, 2018; Accepted: October 03, 2018; Published: October 05,2018 
Fusobacterium nucleatum ATCC 10953, Prevotella intermedia ATCC 25611, and Porphylomonas gingivalis ATCC 33277. Brain-Heart Infusion (Difco Laboratories, Detroit, MI) broth supplemented with $1 \%$ yeast extract (Difco) was used for all bacterial strains except $P$. intermedia and $P$. gingivalis. For $P$. intermedia and $P$. gingivalis, BHI broth containing hemin $1 \mu \mathrm{g} / \mathrm{mL}$ (Sigma, St. Louis, MO, USA) and menadione $1 \mu \mathrm{g} / \mathrm{mL}$ (Sigma) was used.

\section{Minimum inhibitory concentrations/minimum bactericidal concentrations assay}

The minimum inhibitory concentrations (MICs) were determined for the methanol extract of Trichosanthes kirilowii (METK) by the broth dilution method and were carried out in triplicate. The antibacterial activities were examined after incubation at $37^{\circ} \mathrm{C}$ for $18 \mathrm{~h}$ (facultative anaerobic bacteria), for $24 \mathrm{~h}$ (microaerophilic bacteria), and for 1-2 days (obligate anaerobic bacteria) under anaerobic conditions. MICs were determined as the lowest concentration of test samples that resulted in a complete inhibition of visible growth in the broth. $\mathrm{MIC}_{50} \mathrm{~s}$ and $\mathrm{MIC}_{90} \mathrm{~s}$, defined as MICs at which, 50 and $90 \%$, respectively of oral bacteria were inhibited, were determined. Following anaerobic incubation of MICs plates, the minimum bactericidal concentrations (MBCs) were determined on the basis of the lowest concentration of METK that kills $99.9 \%$ of the test bacteria by plating out onto each appropriate agar plate. Ampicillin and gentamicin (Sigma) were used as standard antibiotics in order to compare the sensitivity of METK against oral bacteria.

\section{Checker-board dilution test}

The antibacterial effects of a combination of METK, which exhibited the highest antimicrobial activity, and antibiotics were assessed by the checkerboard test as previously described [18]. The antimicrobial combinations assayed included METK in with antibiotics, ampicillin and gentamicin. Serial dilutions of two different antimicrobial agents were mixed in cation-supplemented Mueller-Hinton broth. After 24-48 $\mathrm{h}$ of incubation at $37^{\circ} \mathrm{C}$, the MICs were determined to be the minimal concentration at which there was no visible growth and $\mathrm{MBCs}$ were determined on the basis of the lowest concentration of METK that kills $99.9 \%$ of the test bacteria by plating out onto each appropriate agar plate. The fractional inhibitory concentration (FIC)/ fractional bactericidal concentration (FBC) index was calculated according to the equation: FIC/FBC index $=$ FIC $/ \mathrm{FBC}_{\mathrm{A}}+\mathrm{FIC} / \mathrm{FBC}_{\mathrm{B}}=(\mathrm{MIC} / \mathrm{MBC}$ of drug $\mathrm{A}$ in combination/MIC/MBC of drug $\mathrm{A}$ alone) $+(\mathrm{MIC} / \mathrm{MBC}$ of drug $B$ in combination/MIC/MBC of drug B alone). The FIC and FBC index are the sum of the FICs and FBCs of each of the drugs, which in turn is defined as the MIC and MBC of each drug when it is used in combination divided by the MIC and MBC of the drug when it is used alone. The interaction was defined as synergistic if the FIC and FBC index was less than or equal to 0.5 , additive if the FIC and FBC index was greater than 0.5 and less than or equal 1.0, indifferent if the FIC and $\mathrm{FBC}$ index was greater than 1.0 and less than or equal to 2.0 , and antagonistic if the FIC and FBC index was greater than 2.0.

\section{Biofilm formation assay}

Evaluation of the effect of METK on biofilm formation of oral bacteria by crystal violet biofilm formation assay was performed according to previous studies [19]. Briefly, $200 \mu \mathrm{L}$ aliquots of treated oral bacteria (final concentration of $1.0 \times 10^{6} \mathrm{CFU} / \mathrm{mL}$ ) at sub-lethal dose of METK (1/2 MIC) plus antibiotics (1/8 MIC) was transferred to a flat-bottomed sterile polystyrene microplate and incubated for 24-48 $\mathrm{h}$ at $37^{\circ} \mathrm{C}$ under anaerobic conditions to form biofilm. Then, cells were washed with phosphate-buffered saline (PBS), stained with $0.1 \%$ (wt/ vol) crystal violet solution for $15 \mathrm{~min}$, washed with PBS, and de-stained with $96 \%$ ethanol $10 \mathrm{~min}$ in order to fix the cells. Thereafter, the wells were rinsed and air-dried. 33\% (vol/vol) acetic acid was then added to each well and biofilm formation was quantified by measuring the absorbance of the solution at $540 \mathrm{~nm}$ using a microplate reader (BMG LABTECH, USA).

\section{Time-kill and growth inhibition curves assay}

Bactericidal activities of the drugs under study were also evaluated using time-kill curves on oral bacteria. Tubes containing MuellerHinton supplemented to which antibiotics had been added at concentrations of the $\mathrm{MIC}_{50}$ were inoculated with a suspension of the test strain, giving a final bacterial count between $5 \sim 7 \times 10^{6} \mathrm{CFU} / \mathrm{mL}$. The tubes were thereafter incubated at $37^{\circ} \mathrm{C}$ in an anaerobic chamber and viable counts were performed at $0,0.5,1,2,3,4,5,6,12$ and $24 \mathrm{~h}$ after addition of antimicrobial agents, on agar plates incubated for up to 48 $\mathrm{h}$ in anaerobic chamber at $37^{\circ} \mathrm{C}$. Antibiotic carryover was minimized by washings by centrifugation and serial 10 -fold dilution in sterile phosphate-buffered saline, $\mathrm{pH}$ 7.3. Colony counts were performed in duplicate, and means were taken. The solid media used for colony counts were $\mathrm{BHI}$ agar for streptococci and $\mathrm{BHI}$ agar containing hemin and menadione for $P$. intermedia and $P$. gingivalis.

\section{Statistical analysis}

Experiments were performed three times and statistical analyses were performed with parametric tests (two-way analysis of variance [ANOVA]) using commercial software (SPSS 22.0). The results were expressed as mean values \pm standard deviations (mean \pm SD) and were considered significant at the level of $\mathrm{p}<0.05$.

\section{Results \& discussion}

\section{Minimum inhibitory concentrations/minimum bactericidal concentrations of METK and antibiotics}

The main etiological factor of dental caries and periodontal disease is dental plaque [20-22]. The known flavonoids of Trichosanthes kirilowii were including quercetin-3-O-[ $\alpha-1-\operatorname{rhamnose}(1 \rightarrow 2)-\beta$ d-glucopyranosyl]-5-O- $\beta$-d-glucopyranoside, quercetin-3-Orutinoside, apigenin-7-O- $\beta$-d-glucopyranoside, diosmetin-7-O- $\beta$ $\mathrm{d}$-glucopyranoside, luteolin, apigenin, and diosmetin [23,24]. These substances show inhibitory effects on glycolytic acid production and GTF activity of $S$. mutans and $S$. sobrinus as well as antimicrobial activities [25-27]. Apigenin exhibits moderate inhibitory effects on the activity of F-ATPase (25\% inhibition), which could affect the acidtolerance of S. mutans [27]. Luteolin, one of the components of perilla seed, showed the strongest antimicrobial effect among the phenolic compounds on dental caries and periodontal diseases [28]. The results of the antimicrobial activity showed that METK exhibited antimicrobial activities against cariogenic bacteria and periodontopathogenic bacteria at dose-dependent manner (Figures 1 and 2). The METK indicated as MICs, 156 to $1250 \mu \mathrm{g} / \mathrm{mL}$; MBCs, 313 to $5000 \mu \mathrm{g} / \mathrm{Ml}$ in cariogenic bacteria and periodontopathogenic bacteria at MICs, 1250 to $2500 \mu \mathrm{g} /$ $\mathrm{mL}$; MBCs, 2500 to $5000 \mu \mathrm{g} / \mathrm{mL}$ and for ampicillin, either $0.25 / 0.25$ or $64 / 64 \mu \mathrm{g} / \mathrm{mL}$; for gentamicin, either $0.5 / 1$ or $256 / 512 \mu \mathrm{g} / \mathrm{mL}$ on tested all bacteria (Table 1). The $\mathrm{MIC}_{50}$ and $\mathrm{MIC}_{90}$ ranges of METK were from 92.37 to $918.42 \mu \mathrm{g} / \mathrm{mL}$ and 156 to $2500 \mu \mathrm{g} / \mathrm{mL}$, respectively. The METK showed stronger antimicrobial activity against cariogenic bacteria than periodontopathogenic bacteria.

\section{Synergistic effect of METK with antibiotics}

The extensive use of these antimicrobial agents can lead to some side-effects, such as tooth staining, calculus formation, drug resistance 

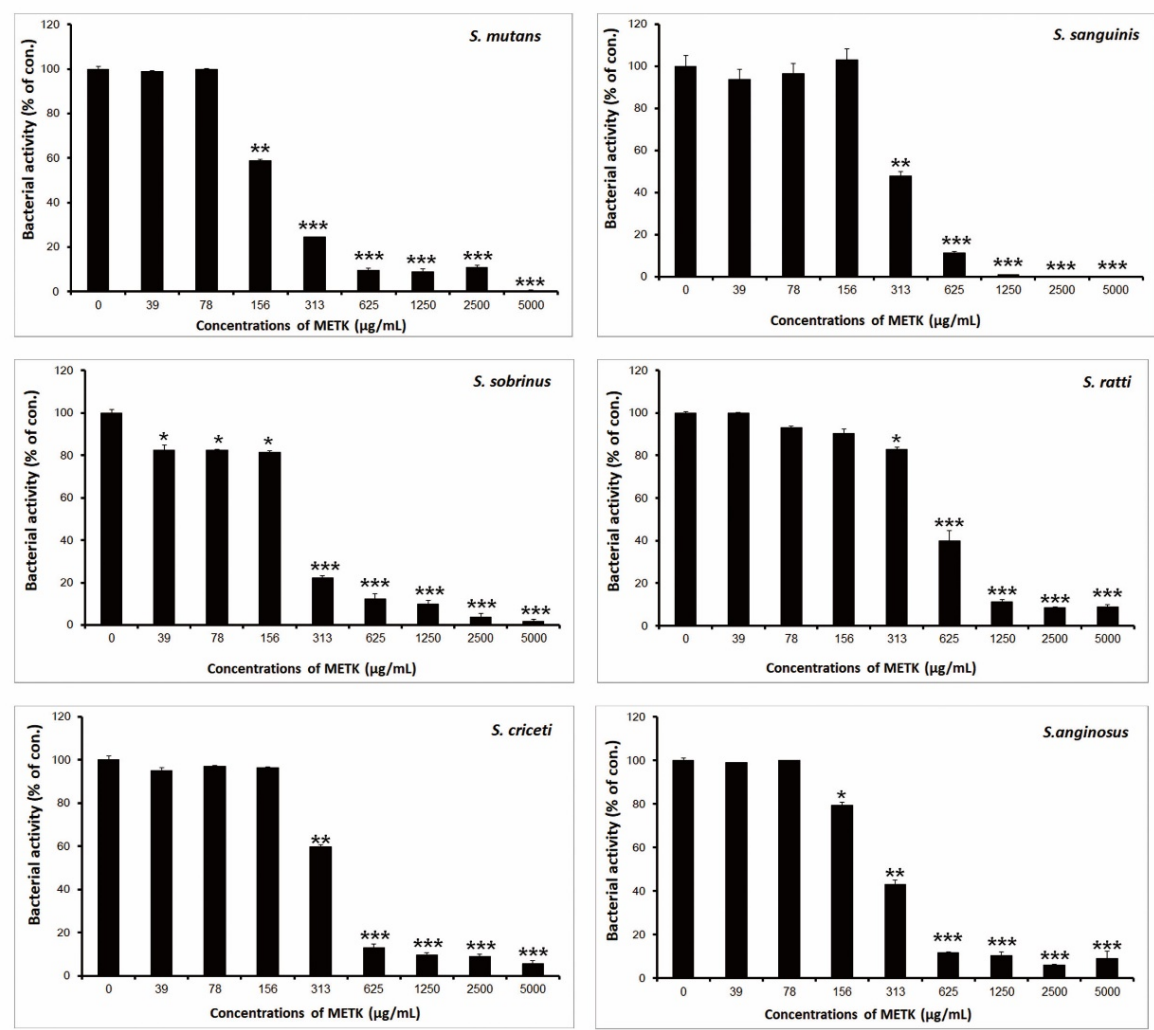

Figure 1. Antibacterial activity of the methanol extract of Trichosanthes kirilowii (METK) against $S$. mutans, S. sanguinis, $S$. sobrinus, $S$. ratti, S. criceti, and $S$. anginosus. Bacteria were incubated with several concentrations of METK for $24 \mathrm{~h}$. Data are presented as the mean $\pm \mathrm{SD}(\mathrm{n}=6, * \mathrm{p}<0.05, * * \mathrm{p}<0.01, * * * \mathrm{p}<0.001$ vs. control group)
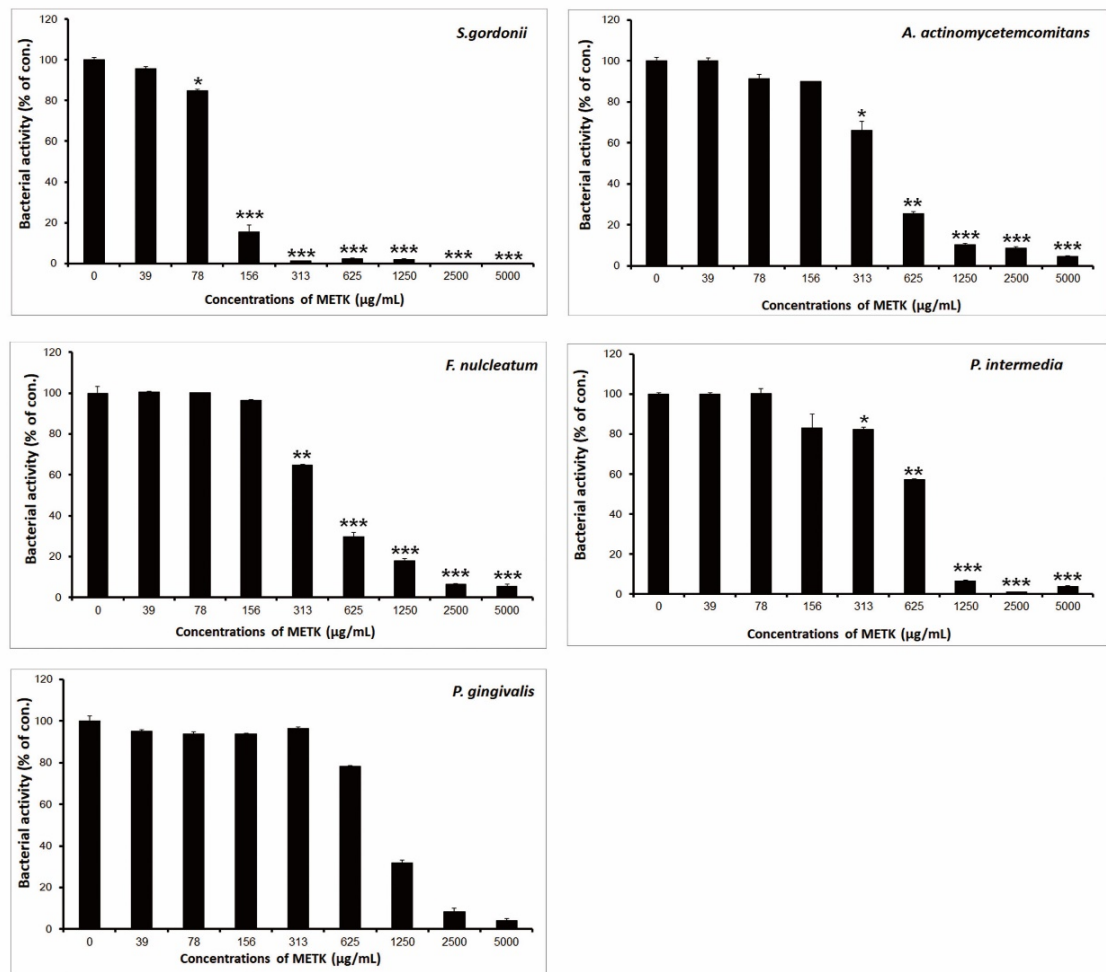

Figure 2. Antibacterial activity of the methanol extract of Trichosanthes kirilowii (METK) against S. gordonii, A. actinomycetemcomitans, F. nucleatum, P. intermedia, and P. gingivalis. Bacteria were incubated with several concentrations of METK for $24 \mathrm{~h}$. Data are presented as the mean $\pm \operatorname{SD}\left(\mathrm{n}=6,{ }^{*} \mathrm{p}<0.05, * * \mathrm{p}<0.01, * * * \mathrm{p}<0.001 \mathrm{vs}\right.$. control group) 
and gastrointestinal reactions [29-31]. Therefore, searching for new antimicrobial molecules, which exhibit few or no side-effects and longterm retention in oral cavity, has been intensified in recent years [3234]. Combinations of some herbal materials and different antibiotics might affect the inhibitory effect of these antibiotics [35,36]. The synergistic effects of METK alone or with antibiotics were evaluated in oral bacteria (Tables 2 and 3). In combination with METK, the MIC for ampicillin was reduced $\geq 4$-fold in tested bacteria, except $S$. sobrinus and $S$. anginosus producing a synergistic effect as defined by $\mathrm{FICI} \leq 0.5$. The MBC for ampicillin was shown synergistic effects in S. sanguinis, $S$. gordonii, A. actinomycetemcomitans, and $P$. gingivalis by $\mathrm{FBCI} \leq 0.5$ (Table 2). In combination with METK, the MIC for gentamicin was reduced $\geq 4$-fold in all tested bacteria except $S$. anginosus by $\mathrm{FICI} \leq 0.5$ and MBC in S. sanguinis, S. sobrinus, S. ratti, S. criceti, F. nucleatum, $P$. intermedia, and P. gingivalis by $\mathrm{FBCI} \leq 0.5$ (Table 3 ).

\section{Anti-biofilm formation of METK with antibiotics}

Many antimicrobial preparations, such as conventional antibiotics, chlorhexidine (CHX), phenolic compounds and triclosan, can inhibit bacteria and biofilm effectively [32,37-39]. Apigenin (4', 5, 7 -trihydroxyflavone) is a potent inhibitor of water insoluble glucans synthesis; $\quad t t$-farnesol (3,7,11-trimethyl-2,6,10-dodecatrien-1-ol), displays activities against streptococcal membranes by increasing their proton permeability and inhibits acid production by $S$. mutans within biofilms $[27,40]$.

Table 1. Minimum inhibitory concentrations (MICs) and minimum bactericidal concentrations (MBCs) of the methanol extract of Trichosanthes kirilowii (METK) against oral bacteria

\begin{tabular}{|c|c|c|c|c|c|}
\hline \multirow{3}{*}{$\begin{array}{l}\text { Strains } \\
\text { S. mutans ATCC } 25175\end{array}$} & \multicolumn{3}{|c|}{$\operatorname{METK}(\mu \mathrm{g} / \mathrm{mL})$} & \multicolumn{2}{|c|}{ Gentamicin } \\
\hline & \multirow{2}{*}{$\begin{array}{c}\mathbf{M I C}_{\mathbf{5 0}} \\
132.7\end{array}$} & \multirow{2}{*}{$\begin{array}{c}\text { MIC }_{90} \\
623\end{array}$} & \multicolumn{3}{|c|}{$\mathrm{MIC} / \mathrm{MBC}$} \\
\hline & & & $625 / 2500$ & $4 / 4$ & $8 / 8$ \\
\hline S. sanguinis ATCC 10556 & 299.45 & 625 & $625 / 1250$ & $32 / 32$ & $8 / 16$ \\
\hline S. sobrinus ATCC 27607 & 201.49 & 625 & $625 / 2500$ & $2 / 2$ & $4 / 8$ \\
\hline S. retti KCTC 3294 & 520.68 & 1250 & $1250 / 5000$ & $4 / 4$ & $4 / 8$ \\
\hline S. criceti KCTC 3292 & 389.87 & 625 & $625 / 2500$ & $4 / 4$ & $8 / 8$ \\
\hline S.anginosus ATCC 31412 & 274.34 & 625 & $625 / 1250$ & $4 / 4$ & $16 / 16$ \\
\hline S. gordonii ATCC 10558 & 92.37 & 156 & $156 / 313$ & $1 / 2$ & $2 / 4$ \\
\hline $\begin{array}{l}\text { A. actinomycetemcomitans } \\
\text { ATCC } 43717\end{array}$ & 419.66 & 1250 & $1250 / 5000$ & $64 / 64$ & $2 / 2$ \\
\hline F. nucleatum ATCC 51190 & 447.14 & 2500 & $2500 / 5000$ & $0.25 / 0.25$ & $16 / 32$ \\
\hline P. intermedia ATCC 49046 & 522.45 & 1250 & $1250 / 2500$ & $32 / 32$ & $0.5 / 1$ \\
\hline P. gingivalis ATCC 33277 & 918.42 & 2500 & $2500 / 5000$ & $0.5 / 1$ & $256 / 512$ \\
\hline
\end{tabular}

${ }^{1}$ American Type Culture Collection (ATCC)

${ }^{2}$ Korean collection for type cultures (KCTC)

Table 2. Checkerboard assay of the methanol extract of Trichosanthes kirilowii (METK) and ampicillin against oral bacteria

\begin{tabular}{|c|c|c|c|c|c|c|}
\hline \multirow{2}{*}{ Strains } & \multirow{2}{*}{ Agent } & \multicolumn{2}{|c|}{ MIC/MBC $(\mu \mathrm{g} / \mathrm{mL})$} & \multirow{2}{*}{ FIC/FBC } & \multirow{2}{*}{ FICI/FBCI ${ }^{2}$} & \multirow{2}{*}{ Outcome } \\
\hline & & Alone & Combination $^{1}$ & & & \\
\hline \multirow{2}{*}{$\begin{array}{c}\text { S. mutans } \\
{ }^{3} \text { ATCC } 25175\end{array}$} & METK & $625 / 2500$ & $156 / 625$ & $0.25 / 0.25$ & \multirow{2}{*}{$0.5 / 0.75$} & \multirow{2}{*}{$\begin{array}{c}\text { Synergistic/ } \\
\text { Additive }\end{array}$} \\
\hline & Ampicillin & $4 / 4$ & $1 / 2$ & $0.25 / 0.5$ & & \\
\hline \multirow{2}{*}{$\begin{array}{l}\text { S. sanguinis } \\
\text { ATCC } 10556\end{array}$} & METK & $625 / 1250$ & $156 / 313$ & $0.25 / 0.25$ & \multirow{2}{*}{$0.375 / 0.5$} & \multirow{2}{*}{$\begin{array}{l}\text { Synergistic/ } \\
\text { Synergistic }\end{array}$} \\
\hline & Ampicillin & $32 / 32$ & $4 / 8$ & $0.125 / 0.25$ & & \\
\hline \multirow{2}{*}{$\begin{array}{l}\text { S. sobrinus } \\
\text { ATCC } 27607\end{array}$} & METK & $625 / 2500$ & $156 / 625$ & $0.25 / 0.25$ & \multirow{2}{*}{$0.75 / 0.75$} & \multirow{2}{*}{$\begin{array}{l}\text { Additive/ } \\
\text { Additive }\end{array}$} \\
\hline & Ampicillin & $2 / 2$ & $1 / 1$ & $0.5 / 0.5$ & & \\
\hline \multirow{2}{*}{$\begin{array}{c}\text { S. retti } \\
\text { 4KCTC } 3294\end{array}$} & METK & $1250 / 5000$ & $313 / 625$ & $0.25 / 0.125$ & \multirow{2}{*}{$0.5 / 0.625$} & \multirow{2}{*}{$\begin{array}{c}\text { Synergistic/ } \\
\text { Additive }\end{array}$} \\
\hline & Ampicillin & $4 / 4$ & $1 / 2$ & $0.25 / 0.5$ & & \\
\hline \multirow{2}{*}{$\begin{array}{c}\text { S. criceti } \\
\text { KCTC } 3292\end{array}$} & METK & $625 / 2500$ & $156 / 625$ & $0.25 / 0.25$ & \multirow{2}{*}{$0.5 / 0.75$} & \multirow{2}{*}{$\begin{array}{l}\text { Synergistic/ } \\
\text { Additive }\end{array}$} \\
\hline & Ampicillin & $4 / 4$ & $1 / 2$ & $0.25 / 0.5$ & & \\
\hline \multirow{2}{*}{$\begin{array}{l}\text { S. anginosus } \\
\text { ATCC } 31412\end{array}$} & METK & $625 / 1250$ & $\begin{array}{c}313 / 625 \\
1 /\end{array}$ & $0.5 / 0.5$ & \multirow[t]{2}{*}{$0.75 / 1.0$} & \multirow{2}{*}{$\begin{array}{l}\text { Additive/ } \\
\text { Additive }\end{array}$} \\
\hline & Ampicillin & $4 / 4$ & $1 / 2$ & $0.25 / 0.5$ & & \\
\hline \multirow{2}{*}{$\begin{array}{c}\text { S. gordonii } \\
\text { ATCC } 10558\end{array}$} & METK & $156 / 313$ & $39 / 78$ & $0.25 / 0.25$ & \multirow{2}{*}{$0.5 / 0.5$} & \multirow{2}{*}{$\begin{array}{l}\text { Synergistic/ } \\
\text { Synergistic }\end{array}$} \\
\hline & Ampicillin & $1 / 2$ & $0.25 / 0.5$ & $0.25 / 0.25$ & & \\
\hline \multirow{2}{*}{$\begin{array}{c}A . \\
\text { actinomycetemcomitans } \\
\text { ATCC } 43717\end{array}$} & METK & $1250 / 5000$ & $313 / 625$ & $0.25 / 0.125$ & \multirow{2}{*}{$0.375 / 0.375$} & \multirow{2}{*}{$\begin{array}{l}\text { Synergistic/ } \\
\text { Synergistic }\end{array}$} \\
\hline & Ampicillin & $64 / 64$ & $8 / 16$ & $0.125 / 0.25$ & & \\
\hline \multirow{2}{*}{$\begin{array}{l}\text { F. nucleatum } \\
\text { ATCC } 51190\end{array}$} & METK & $2500 / 5000$ & $313 / 625$ & $0.125 / 0.125$ & \multirow{2}{*}{$0.375 / 0.625$} & \multirow{2}{*}{$\begin{array}{c}\text { Synergistic/ } \\
\text { Additive }\end{array}$} \\
\hline & Ampicillin & $0.25 / 0.25$ & $0.063 / 0.125$ & $0.25 / 0.5$ & & \\
\hline \multirow{2}{*}{$\begin{array}{l}\text { P. intermedia } \\
\text { ATCC } 49049\end{array}$} & METK & $1250 / 2500$ & $313 / 625$ & $0.25 / 0.25$ & $5-5=75$ & Synergistic/ \\
\hline & Ampicillin & $32 / 32$ & $8 / 16$ & $0.25 / 0.5$ & $0.5 / 0.75$ & Additive \\
\hline P. gingivalis & METK & $2500 / 5000$ & $625 / 625$ & $0.25 / 0.125$ & & Synergistic/ \\
\hline ATCC 33277 & Ampicillin & $0.5 / 1$ & $0.125 / 0.25$ & $0.25 / 0.25$ & $0.5 / 0.375$ & Synergistic \\
\hline
\end{tabular}

${ }^{1}$ The MIC and MBC of the methanol extract of Trichosanthes kirilowii (METK) with ampicillin

${ }^{2}$ The fractional inhibitory concentration (FIC) index/fractional bactericical concentration (FBC) index

${ }^{3}$ American Type Culture Collection (ATCC)

${ }^{4}$ Korean collection for type cultures (KCTC) 
In this study, METK $1 / 8$ MIC with ampicillin 1/8 MIC effectively inhibited the formation of $S$. mutans, S. sobrinus, S. ratti, S. anginosus, and $P$. intermedia biofilms, with nearly $80 \%$ or more biofilm inhibition and gentamicin inhibited more than $80 \%$ biofilm formation in $S$. anginosus and nearly $80 \%$ effective in S. mutnas, S. gordonii, and P. intermedia (Figure 3).

\section{Time kill of METK with antibiotics}

The type of microorganisms and their cell membrane structure and composition could play an important role in the susceptibility to antimicrobials [40-42]. The flavonoids of plant exerting its antibacterial effects is connected with disruption of the cytoplasmic membrane and

Table 3. Checkerboard assay of the methanol extract of Trichosanthes kirilowii (METK) and gentamicin against oral bacteria

\begin{tabular}{|c|c|c|c|c|c|c|}
\hline \multirow{2}{*}{ Strains } & \multirow{2}{*}{ Agent } & \multicolumn{2}{|c|}{$\mathrm{MIC} / \mathrm{MBC}(\mu \mathrm{g} / \mathrm{mL})$} & \multirow{2}{*}{ FIC/FBC } & \multirow{2}{*}{$\mathbf{F I C I} / \mathrm{FBCI}^{2}$} & \multirow{2}{*}{ Outcome } \\
\hline & & Alone & Combination $^{1}$ & & & \\
\hline \multirow{2}{*}{$\begin{array}{l}\text { S. mutans } \\
{ }^{3} \text { ATCC } 25175\end{array}$} & METK & $625 / 2500$ & $156 / 625$ & $0.25 / 0.25$ & \multirow{2}{*}{$0.5 / 0.75$} & \multirow{2}{*}{$\begin{array}{c}\text { Synergistic/ } \\
\text { Additive }\end{array}$} \\
\hline & Gentamicin & $8 / 8$ & $2 / 4$ & $0.25 / 0.5$ & & \\
\hline \multirow{2}{*}{$\begin{array}{l}\text { S. sanguinis } \\
\text { ATCC } 10556\end{array}$} & METK & $625 / 1250$ & $156 / 313$ & $0.25 / 0.25$ & \multirow{2}{*}{$0.5 / 0.5$} & \multirow{2}{*}{$\begin{array}{l}\text { Synergistic/ } \\
\text { Synergistic }\end{array}$} \\
\hline & Gentamicin & $8 / 16$ & $2 / 4$ & $0.25 / 0.25$ & & \\
\hline \multirow{2}{*}{$\begin{array}{l}\text { S. sobrinus } \\
\text { ATCC } 27607\end{array}$} & METK & $625 / 2500$ & $156 / 313$ & $0.25 / 0.125$ & \multirow{2}{*}{$0.5 / 0.375$} & \multirow{2}{*}{$\begin{array}{l}\text { Synergistic/ } \\
\text { Synergistic }\end{array}$} \\
\hline & Gentamicin & $4 / 8$ & $1 / 2$ & $0.25 / 0.25$ & & \\
\hline \multirow{2}{*}{$\begin{array}{l}\text { S. retti } \\
{ }^{4} \text { KCTC } 3294\end{array}$} & METK & $1250 / 5000$ & $313 / 625$ & $0.25 / 0.125$ & \multirow{2}{*}{$0.5 / 0.375$} & \multirow{2}{*}{$\begin{array}{l}\text { Synergistic/ } \\
\text { Synergistic }\end{array}$} \\
\hline & Gentamicin & $4 / 8$ & $1 / 2$ & $0.25 / 0.25$ & & \\
\hline \multirow{2}{*}{$\begin{array}{l}\text { S. criceti } \\
\text { KCTC } 3292\end{array}$} & METK & $625 / 2500$ & $156 / 625$ & $0.25 / 0.25$ & \multirow{2}{*}{$0.375 / 0.5$} & \multirow{2}{*}{$\begin{array}{l}\text { Synergistic/ } \\
\text { Synergistic }\end{array}$} \\
\hline & Gentamicin & $8 / 8$ & $1 / 2$ & $0.125 / 0.25$ & & \\
\hline \multirow{2}{*}{$\begin{array}{l}\text { S. anginosus } \\
\text { ATCC } 31412\end{array}$} & METK & $625 / 1250$ & $313 / 625$ & $0.5 / 0.5$ & \multirow{2}{*}{$0.75 / 0.75$} & \multirow{2}{*}{$\begin{array}{l}\text { Additive/ } \\
\text { Additive }\end{array}$} \\
\hline & Gentamicin & $16 / 16$ & $4 / 4$ & $0.25 / 0.25$ & & \\
\hline \multirow{2}{*}{$\begin{array}{l}\text { S. gordonii } \\
\text { ATCC } 10558\end{array}$} & METK & $156 / 313$ & $39 / 156$ & $0.25 / 0.5$ & \multirow{2}{*}{$0.5 / 1.0$} & \multirow{2}{*}{$\begin{array}{c}\text { Synergistic/ } \\
\text { Additive }\end{array}$} \\
\hline & Gentamicin & $2 / 4$ & $0.5 / 2$ & $0.25 / 0.5$ & & \\
\hline \multirow{2}{*}{$\begin{array}{l}\text { A } \\
\text { actinomycetemcomitans } \\
\text { ATCC } 43717\end{array}$} & METK & $1250 / 5000$ & $313 / 625$ & $0.25 / 0.125$ & \multirow[b]{2}{*}{$0.375 / 0.375$} & \multirow{2}{*}{$\begin{array}{c}\text { Synergistic/ } \\
\text { Additive }\end{array}$} \\
\hline & Gentamicin & $2 / 2$ & $0.25 / 0.5$ & $0.125 / 0.25$ & & \\
\hline \multirow{2}{*}{$\begin{array}{l}\text { F. nucleatum } \\
\text { ATCC } 51190\end{array}$} & METK & $2500 / 5000$ & $625 / 1250$ & $0.25 / 0.25$ & \multirow{2}{*}{$0.5 / 0.5$} & \multirow{2}{*}{$\begin{array}{l}\text { Synergistic/ } \\
\text { Synergistic }\end{array}$} \\
\hline & Gentamicin & $16 / 32$ & $4 / 8$ & $0.25 / 0.25$ & & \\
\hline \multirow{2}{*}{$\begin{array}{l}\text { P. intermedia } \\
\text { ATCC } 49049\end{array}$} & METK & $1250 / 2500$ & $313 / 625$ & $0.25 / 0.25$ & $0.5 / 0.5$ & Synergistic/ \\
\hline & Gentamicin & $0.5 / 1$ & $0.125 / 0.25$ & $0.25 / 0.25$ & $0.2 / 0.5$ & Synergistic \\
\hline P. gingivalis & METK & $2500 / 5000$ & $625 / 1250$ & $0.25 / 0.25$ & $0.5 / 0375$ & Synergistic/ \\
\hline ATCC 33277 & Gentamicin & $256 / 512$ & $64 / 64$ & $0.25 / 0.125$ & $0.0 / 0.3 / 3$ & Synergistic \\
\hline
\end{tabular}

${ }^{1}$ The MIC and MBC of the methanol extract of Trichosanthes kirilowii (METK) with gentamicin

${ }^{2}$ The fractional inhibitory concentration (FIC) index/fractional bactericical concentration (FBC) index

${ }^{3}$ American Type Culture Collection (ATCC)

${ }^{4}$ Korean collection for type cultures (KCTC)
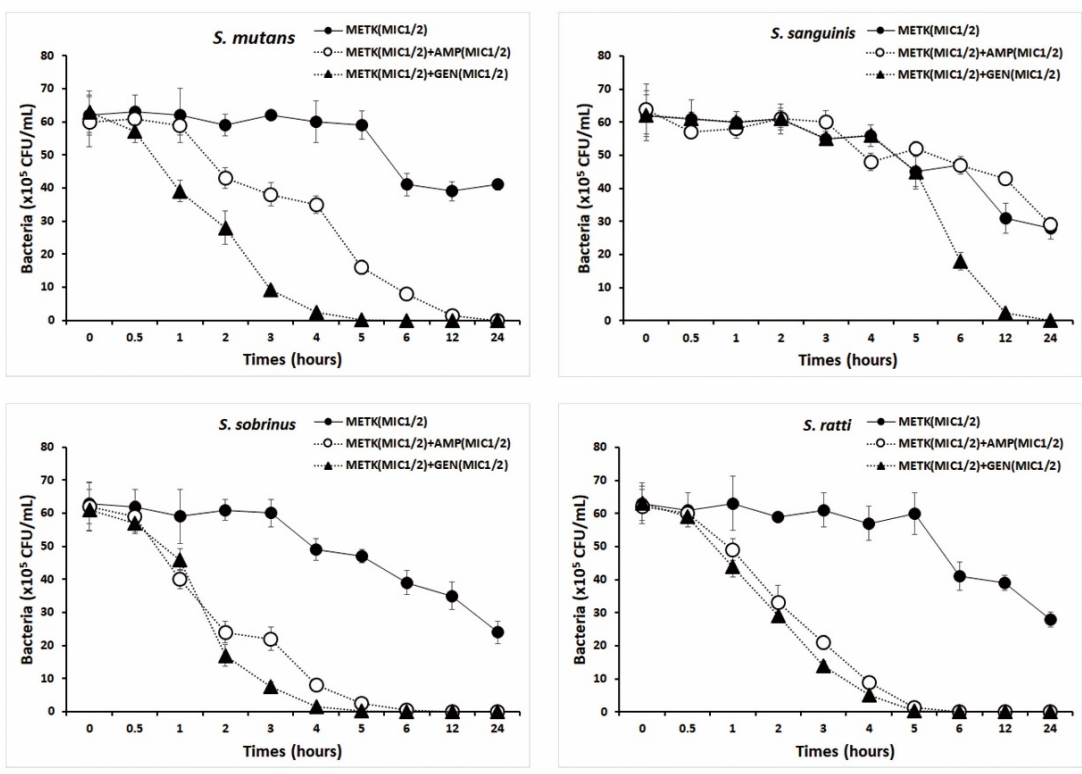

Figure 3. Time-kill curves of MICs of the methanol extract of Trichosanthes kirilowii (METK) alone and in combination with MICs of ampicillin or gentamicin against $S$. mutans, $S$ sanguinis, $S$. sobrinus, and $S$. ratti. Bacteria were incubated with METK along $(\bullet)$, METK with ampicillin $(\circ)$, and METK with gentamicin $(\boldsymbol{\Lambda})$ over time. Data are presented as the mean $\pm \mathrm{SD}$ of the four experiments. CFU, colony-forming units 
DNA targeting effects in microorganisms [42,43]. The bacterial effect of METK with antibiotics, ampicillin and gentamicin against oral bacteria was confirmed by time-kill curve experiments. The METK (MIC or $\mathrm{MIC}_{50}$ ) alone resulted rate of killing increasing or not changing in $\mathrm{CFU} / \mathrm{ml}$ at time dependent manner, with a more rapid rate of killing by METK $\left(\mathrm{MIC}_{50}\right.$ ) with ampicillin and/or gentamicin $\left(\mathrm{MIC}_{50}\right.$ ) (Figures 4 and 5). A strong bactericidal effect was exerted in drug combinations.

Indeed, the flavonoids inhibitory action against cariogenic bacteria has been suspected since long time [44]. The aqueous extracts contain more polar compounds, which are probably less effective against cariogenic bacteria, due to the strong hydrophobicity of their cell surfaces $[45,46]$. Inhibition of bacterial adherence to skin, mucosal and dental surfaces facilitated by topical application may also have beneficial effects in the prevention of infectious diseases, dental caries and periodontal disease. Plant phenolics-covered medical device surfaces may help in prevention of device-associated biofilm infections. The METK showed stronger antibacterial activity and antibiofilm formation against cariogenic bacteria than periodontic bacteria.
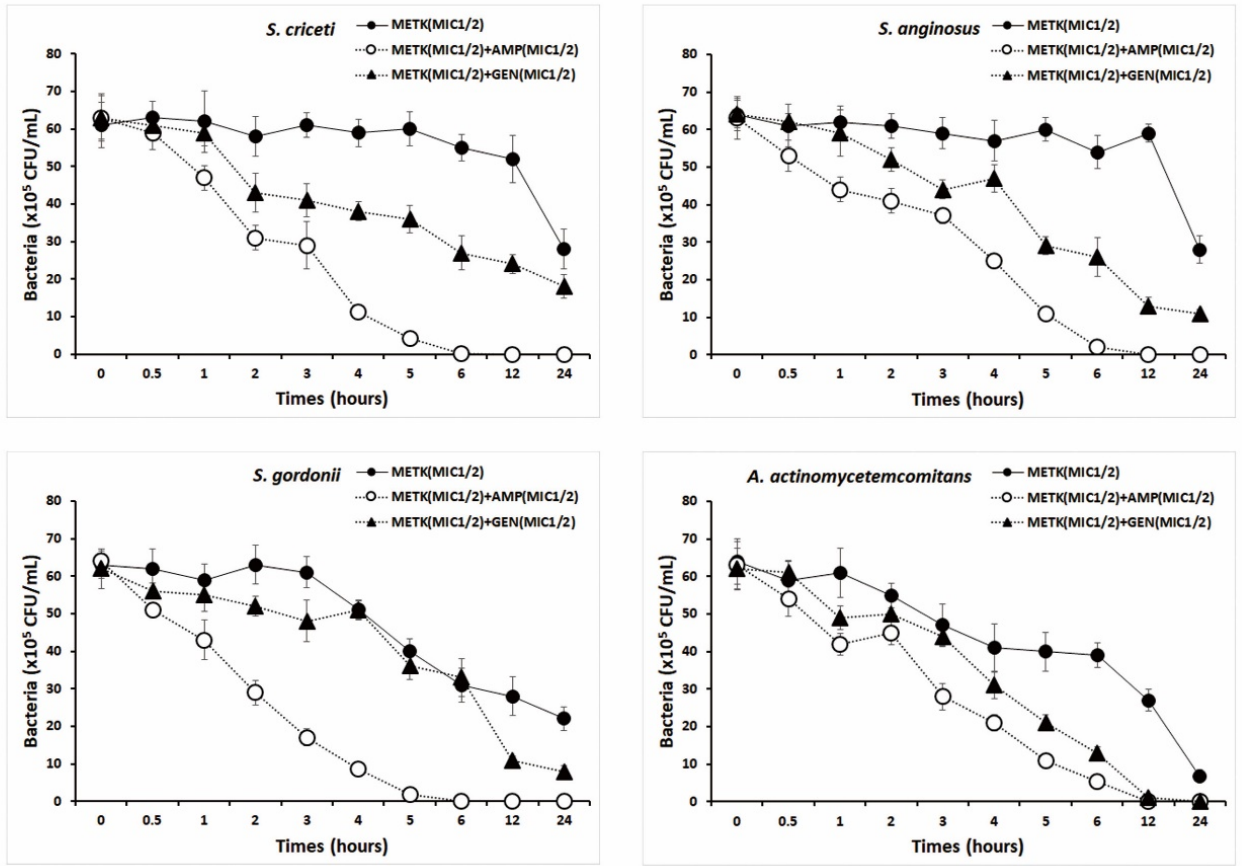

Figure 4. Time-kill curves of MICs of the methanol extract of Trichosanthes kirilowii (METK) alone and in combination with MICs of ampicillin or gentamicin against $S$. criceti, $S$. anginosus, S. gordonii, and A. actinomycetemcomitans. Bacteria were incubated with METK along $(\bullet)$, METK with ampicillin (०), and METK with gentamicin $(\boldsymbol{\Delta})$ over time. Data are presented as the mean $\pm \mathrm{SD}$ of the four experiments. CFU, colony-forming units
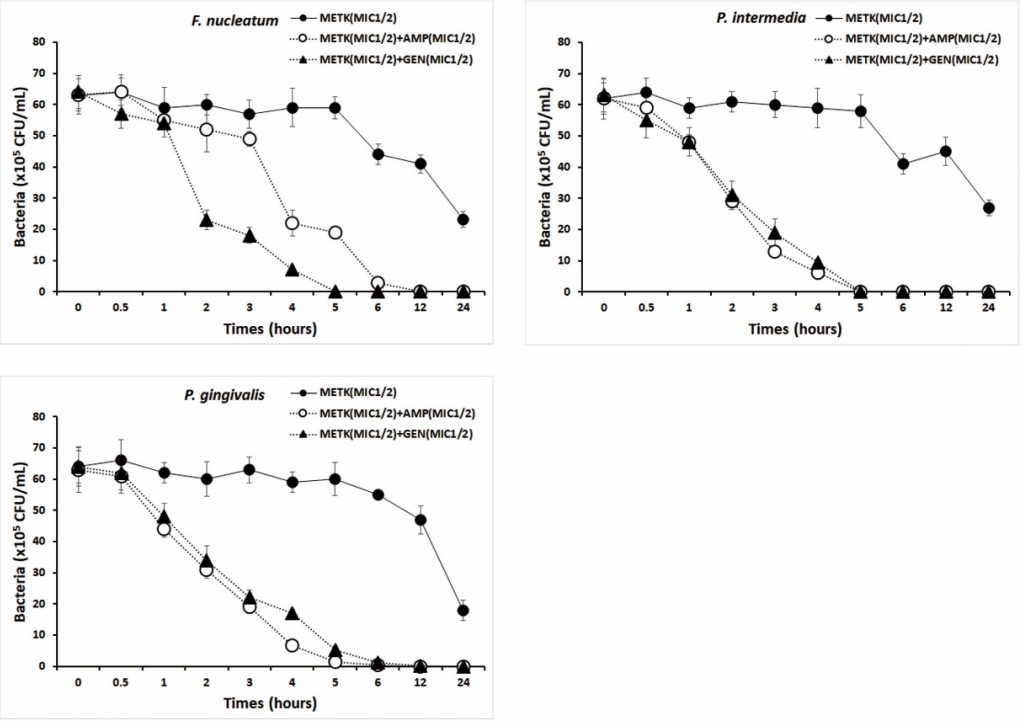

Figure 5. Time-kill curves of MICs of the methanol extract of Trichosanthes kirilowii (METK) alone and its combination with MICs of ampicillin or gentamicin against $F$. nucleatum, $P$. intermedia, and P. gingivalis. Bacteria were incubated with METK along $(\bullet)$, METK with ampicillin $(\circ)$, and METK with gentamicin $(\boldsymbol{\Delta})$ over time. Data are presented as the mean \pm SD of the four experiments. CFU, colony-forming units 
In conclusion, these findings suggest that METK fulfills the conditions required of a novel cariogenic bacteria and periodontal pathogens, particularly bacteroides species drug and may be useful in the future in the treatment of oral bacteria.

\section{Declaration of interest}

The authors declare no conflict of interest.

\section{Sources of funding}

This study was not funded by any organization.

\section{Ethical approval}

This study has no need for prior approval by an ethics committee.

\section{References}

1. Mira A, Simon-Soro A, Curtis MA (2017) Role of microbial communities in the pathogenesis of periodontal diseases and caries. J Clin Periodontol 18: S23-23S38. [Crossref]

2. Borgnakke WS (2015) Does treatment of periodontal disease influence systemic disease? Dent Clin North Am 59: 885-917. [Crossref]

3. Legéňová K, Bujdáková H (2015) The role of Streptococcus mutans in the oral biofilm. Epidemiol Mikrobiol Imunol 64: 179-187. [Crossref]

4. Larsen T, Fiehn NE (2017) Dental biofilm infections - an update. APMIS 125: 376-384. [Crossref]

5. Marsh PD, Zaura E (2017) Dental biofilm: ecological interactions in health and disease. J Clin Periodontol 44 Suppl 18: S12-12S22. [Crossref]

6. Struzycka I (2014) The oral microbiome in dental caries. Pol J Microbiol 63: 127-135. [Crossref]

7. Di Benedetto A, Gigante I, Colucci S, Grano M (2013) Periodontal disease: linking the primary inflammation to bone loss. Clin Dev Immunol 2013: 503754. [Crossref]

8. Lv X, Zhang Y, Zhang H (2018) Neuroprotective effect of Trichosanthes kirilowii cassia twig on cerebral ischmia-reperfusion injury in rats. PakJ Pharm Sci 31: 1643-1647.

9. Jin ZQ, Hao J, Yang X, He JH, Liang J, et al. (2018) Higenamine enhances the antitumor effects of cucurbitacin B in breast cancer by inhibiting the interaction of AKT and CDK2. Oncol Rep 40: 2127-2136. [Crossref]

10. Lu J, Peng J, Xiang M, He L, Wang D, et al. (2018) Trichosanthes kirilowii lectin alleviates diabetic nephropathy by inhibiting the LOX1/NF-?B/caspase-9 signaling pathway. Biosci Rep 7: 38.

11. Jeong SJ, Choi JY, Dong MS, Seo CS, Shin HK (2017) Trichosanthes kirilowii exerts androgenic activity via regulation of PSA and KLK2 in 22Rv1 prostate cancer cells. Pharmacogn Mag 13: 153-158. [Crossref]

12. Ye X, Ng CC, Wong JH, Ng TB2, Chan GH, et al. (2016) Ribosome-inactivating proteins from root tubers and seeds of trichosan-thes kirilowii and other trichosanthes species. Protein Pept Lett 23: 699-706. [Crossref]

13. Fang EF, Ng TB, Shaw PC, Wong RN (2011) Recent progress in medicinal investigations on trichosanthin and other ribosome inactivating proteins from the plant genus Trichosanthes. Curr Med Chem 18:4410-4417.

14. Song Y, Ding N, Kanazawa T, Yamashita U, Yoshida Y (2013) Cucurbitacin D is a new inflammasome activator in macrophages. Int Immunopharmacol 17: 1044-1050. [Crossref]

15. Takahashi N, Yoshida Y, Sugiura T, Matsuno K, Fujino A, et al. (2009) Cucurbitacin $\mathrm{D}$ isolated from Trichosanthes kirilowii induces apoptosis in human hepatocellular carcinoma cells in vitro. Int Immunopharmacol 9: 508-513

16. Oh H, Mun YJ, Im SJ, Lee SY, Song HJ, et al. (2002) Cucurbitacins from Trichosanthes kirilowii as the inhibitory components on tyrosinase activity and melanin synthesis of B16/F10 melanoma cells. Planta Med 68: 832-833.

17. Bhattacharya S, Biswas M, Haldar PK (2013) The triterpenoid fraction from Trichosanthes dioica root exhibits in vitro antileishmanial effect against Leishmania donovani promatigotes. Pharmacognosy Res 5:109-112.

18. Climo MW, Patron RL, Archer GL (1999) Combinations of vancomycin and betalactams are synergistic against staphylococci with reduced susceptibilities to vancomycin. Antimicrob Agents Chemother 43: 1747-1753.
19. Arzmi MH, Alnuaimi AD, Dashper S, Cirillo N, Reynolds EC, et al. (2016) Polymicrobial biofilm formation by Candida albicans, Actinomyces naeslundii, and Streptococcus mutans is Candida albicans strain and medium dependent. Med Mycol 54: 856-864.

20. Sambunjak D, Nickerson JW, Poklepovic T, Johnson TM, Imai P, et al. (2011) Flossing for the management of periodontal diseases and dental caries in adults. Cochrane Database Syst Rev 7: CD008829.

21. Arweiler NB, Netuschil L (2016) The Oral Microbiota. Adv Exp Med Biol 902: 45-60. [Crossref]

22. Pasich E, Walczewska M, Pasich A, Marcinkiewicz J (2013) Mechanism and risk factors of oral biofilm formation. Postepy Hig Med Dosw (Online) 67: 736-741. [Crossref]

23. Li AF, Sun AL, Liu RM, Zhang YQ (2014) Chemical constituents of Trichosanthes kirilowii peels. Zhong Yao Cai 37: 428-431.

24. Li A, Sun A, Liu R, Zhang Y, Cui J (2014) An efficient preparative procedure for main flavonoids from the peel of Trichosanthes kirilowii Maxim. Using polyamide resin followed by semi-preparative high performance liquid chromatography. J Chromatogr B Analyt Technol Biomed Life Sci 965: 150-157.

25. Yang WY, Kim CK, Ahn CH, Kim H, Shin J, et al. (2016) Flavonoid glycosides inhibit sortase A and sortase A-mediated aggregation of streptococcus mutans, an ora bacterium responsible for human dental caries. J Microbiol Biotechnol 26: 1566-1569.

26. Wallock-Richards DJ, Marles-Wright J, Clarke DJ, Maitra A, Dodds M, et al. (2015) Molecular basis of Streptococcus mutans sortase A inhibition by the flavonoid natural product trans-chalcone. Chem Commun (Camb) 51: 10483-10485.

27. Koo H, Seils J, Abranches J, Burne RA, Bowen WH, et al. (2006) Influence of apigenin on gtf gene expression in Streptococcus mutans UA159. Antimicrob Agents Chemother 50: 542-546. [Crossref]

28. Yamamoto H, Ogawa T (2002) Antimicrobial activity of perilla seed polyphenols against oral pathogenic bacteria. Biosci Biotechnol Biochem 66: 921-924.

29. Zanatta FB, Antoniazzi RP, Rösing CK (2010) Staining and calculus formation after $0.12 \%$ chlorhexidine rinses in plaque-free and plaque covered surfaces: a randomized trial. J Appl Oral Sci 18: 515-521.

30. Diallo T, Adjobimey M, Ruslami R, Trajman A, Sow O, et al. (2018) Safety and side effects of rifampin versus isoniazid in children. N Engl J Med 379: 454-463. [Crossref]

31. Peixoto AC, Vaez SC, Pereira NAR, Santana CNDS, Soares KDA, et al. (2018) High-concentration carbamide peroxide can reduce the sensitivity caused by in-office tooth bleaching: A single-blinded randomized controlled trial. J Appl Oral Sci 26: e20170573. [Crossref]

32. Fernandes T, Bhavsar C, Sawarkar S, D'souza A (2018) Current and novel approaches for control of dental biofilm. Int J Pharm 536: 199-210. [Crossref]

33. da Silva BR, de Freitas VA, Nascimento-Neto LG, Carneiro VA, Arruda FV, et al (2012) Antimicrobial peptide control of pathogenic microorganisms of the oral cavity: a review of the literature. Peptides 36: 315-321.

34. Khurshid Z, Naseem M, Sheikh Z, Najeeb S, Shahab S, et al. (2016) Oral antimicrobial peptides: Types and role in the oral cavity. Saudi Pharm J 24: 515-524. [Crossref]

35. Otto RG, van Gorp E, Kloezen W, Meletiadis J, van den Berg S, et al. (2018) An alternative strategy for combination therapy: Interactions between polymyxin $\mathrm{B}$ and non-antibiotics. Int $J$ Antimicrob Agents.

36. Ahn KB, Kim AR, Kum KY, Yun CH, et al. (2017) The synthetic human beta-defensin-3 C15 peptide exhibits antimicrobial activity against Streptococcus mutans, both alone and in combination with dental disinfectants. J Microbiol 55: 830-836. [Crossref]

37. Gregoire S, Singh AP, Vorsa N, Koo H (2007) Influence of cranberry phenolics on glucan synthesis by glucosyltransferases and Streptococcus mutans acidogenicity. $J$ Appl Microbiol 103: 1960-1968.

38. Seneviratne CJ, Leung KC, Wong CH, Lee SF, Li X, et al. (2014) Nanoparticleencapsulated chlorhexidine against oral bacterial biofilms. PLoS One 9: e103234. [Crossref]

39. Miladi H, Zmantar T, Kouidhi B, Al Qurashi YMA, Bakhrouf A, et al. (2017) Synergistic effect of eugenol, carvacrol, thymol, p-cymene and terpinene on inhibition of drug resistance and biofilm formation of oral bacteria. Microb Pathog 112: 156-163.

40. Jeon JG, Pandit S, Xiao J, Gregoire S, Falsetta ML, et al. (2011) Influences of trans-tran farnesol, a membrane-targeting sesquiterpenoid, on Streptococcus mutans physiology and survival within mixed-species oral biofilms. Int J Oral Sci 3: 98-106. [Crossref]

41. Tagousop CN, Tamokou JD, Ekom SE, Ngnokam D, Voutquenne-Nazabadioko L (2018) Antimicrobial activities of flavonoid glycosides from Graptophyllum grandulosum and their mechanism of antibacterial action. BMC Complement Altern Med 18: 252. [Crossref] 
42. Sarkar P, Acharyya S, Banerjee A, Patra A, Thankamani K, et al. (2016) Intracellular, biofilm-inhibitory and membrane-damaging activities of nimbolide isolated form Aazdirachta indica A. Juss (Meliaceae) against meticillin-resistant Staphylococcus aureus. J Med Microbiol 65: 1205-1214

43. Wang LH, Wang MS, Zeng XA, Xu XM, Brennan CS (2017) Membrane and genomic DNA dual-targeting of citrus flavonoid naringenin against Staphylococcus aureus. Integr Biol (Camb) 9: 820-829. [Crossref]
44. Sato M, Fujiwara S, Tsuchiya H, Fujii T, Linuma M, et al. (1996) Flavones with antibacterial activity against cariogenic bacteria. J Ethnopharmacol 54: 171-176.

45. Nikitina VS, Kuz'mina LY, Melent'ev AI, Shendel GV (2007) Antibacterial activity of polyphenolic compounds isolated from plants of Geraniaceae and Rosaceae families. App Biochem Microbiol 43: 629-634.

46. Weiss E, Rosenberg M, Judes H, Rosenberg E (1982) Cell-surface hydrophobicity of adherent oral bacteria. Curr Microbiol 7: 125-128

Copyright: $(02018$ Jang E. This is an open-access article distributed under the terms of the Creative Commons Attribution License, which permits unrestricted use, distribution, and reproduction in any medium, provided the original author and source are credited. 